\title{
The Transition from Positivism to the Process of Postpositivist/Constructivist in The Elementary School Science Curriculum in Turkey
}

\author{
Faruk ÖZTÜRK*
}

\begin{abstract}
ABSTARCT: The aim of this study is to identify the transformations experienced by the elementary science course in Turkey and reveal the paradigms that affected the objectives and outcomes of the program. The historical development of the process has been divided into two stages. The first one is the later stages of the Ottoman State and the Republican Era, when positivism was prevalent. The second stage includes the period starting from 2004 onwards. The evaluation was based on the objectives and outcomes of the elementary science curriculum. The positivist science approach which was prevalent in the elementary curriculum during the Republican Era is best manifested in the objectives of the science course. This was the case until the year 2004, when the effects of postmodern epistemology started to partially be seen with the initiation of the new elementary curriculum based on the 'constructivist approach'. However, constructivizm is evident mostly in instructional practices and strategies, and did not go beyond pedagogy.
\end{abstract}

Keywords: Elementary school program, science, science course, positivism, constructivism

\footnotetext{
Doç. Dr., Abant İzzet Baysal Üniversitesi, Eğitim Fakültesi, Eğitim Bilimleri Bölümü, Bolu. e-posta: farukozturk2006@gmail.com.
} 


\section{EXTENDED ABSTRACT}

This study is based on the argument that positivism was a main factor in the process known as the Modernization or Westernization of Turkey, during which scientific advancements in the West were followed closely. At the same time, it may be argued that postmodern approaches have also been included in this process recently, as a reaction to the positivist science approach. Both the positivist/modernist paradigm and, more recently, the postmodernist/postpositivist pradigm have become scientifically and epistemologically powerful in the field of education, and mostly in curricula. In the history of education in Turkey, Science has been a course in which this shift was seen most significantly. Thus, the present study aims to identify the epistemological approaches that impacted the objectives and outcomes of the Elementary Science and Technology Curriculum in the past - during the later stages of Ottomans and the Republican era - as well as the new curricula of 2004. In addition, the study also aims to evaluate the transformation experienced in course objectives and outcomes with shifting paradigms. In the study, how this epistemological transformation got into the historical and political ideological purposes, and what some of the deficiencies are will be nested. Because the use of educational reforms as a means of addressing the political and ideological transformation, in turn, particularly the use of these educational reforms in science, factual, and experimental area is an important transformation. That 2004 the basic philosophy of Science and Technology program demonstrated that the epistemological paradigm shift from being a political paradigm, at least, that is intended to show that it has a purpose is aimed. Therefore, the critical approach dealt with in this study aims to display this political paradigm change.

This study was conducted by analyzing curriculum documents starting from the Reform period under the Ottomans, including Primary and Secondary School Curriculum, (1913, 1914), Curricula of Elementary Schools, (1924, 1926,1936, 1948, 1968 and 1992) Elementary Science and Technology Course (Grades 4 and 5) Curriculum (2004) and other official documents. This study was based on document analysis approach. The documents subject to this study, selected to represent specific historical sections and descriptive analysis of data obtained from this approach, based on historical documentation were examined. During descriptive analysis process, the programs of the course topics, learning outcomes (gains) and epistemelogic language and propositions used in expressions such as objectives were discussed through an analytical approach. Almost all of these documents that are subject to the review are made up of official school 
programs. The criteria in the selection of the document was the education programs used in the historical periods that form the framework of the study. There is not a deviation from the basic paradigm and scientific understanding. Moreover, the approach of the study is not to put forward the changes in science programs by years, its aim is to compare and evaluate the basic approaches that effect the epitemological attitude and basic knowledge philosophy.

The science course was included in elementary schools for the first time in 1924. It was also the first time in the educational history of the country that objectives had been specified for a particular course. The positive science approach and knowledge production methods were used in these principles. These principles include the following: The topics of animals and plants through observation and experiments on living samples. The students should record the outcomes of their observation and experiments. (MV 1341[1925], p. 40) Methods such as experimentation, observation, and research in an authentic environment were recommended for teaching science topics, and it was stated that lecturing and theoretical presentation be avoided. The recommended methods were (MV 1340 [1924]): Research/investigation, observation, observation in an authentic setting, teaching scientific principles, presentation of physiological structures, examining samples, comparison, working on cadavers and autopsy, summarizing research results and evaluation and discussion. In addition to these methods, aims such as 'giving students practical information about everyday objects and introducing the laws obtained through scientific processes' (MV 1340[1924], p.38) are methods and processes that belong to positive knowing and knowledge production processes.

In the era mentioned above, despite the positivist approach following from a materialist ontological base and the dominant discourse of the day, a different approach from today's paradigms existed. This different approach is defined as the 'constructivist' learning approach based on the 'postmodern/postpositivist epistemology'. Knowledge is taken as developmental, objective and applicable/consistent explanations, not transmitted and discovered truths. During the transition to the postmodern age, Turkish curricula also became affected by the transformation of science and knowledge which was observed throughout the world as a result of globalization. Classical positivism was prominent both in the last century of Ottomans and during the Republican era. Although it was followed by the intellectuals of both eras, positivism was not a thought practice born out of profound scientific and philosophical debates. It was taken from the West as the basis of modernity, without first having experienced the period of Enlightenment that Westerners did. Due to this, positivist thinking was 
adopted by not clearly understanding what it entails. Particularly as a political discourse, there was a partially superficial positivist perspective. It therefore remained an imported thought used for ideological and political aims. However, it presented itself more clearly as both a method and a way of knowledge production in the objectives of the science course in the elementary curriculum of the Republican era. This was the case until the year 2004. The effects of the postmodern epistemological attitude started to partially be seen with the adoption of the 'constructivist learning approach' by the new elementary curriculum initiated in 2004. However, this approach may also be said to work superficially and with an ideological orientation, similar to positivism which was copied from the West. Indeed, the constructivist approach was used mostly by the instructional practices and strategies of the Science and Technology Curriculum, and did not go beyond pedagogy. 


\title{
Türkiye'de İlköğretim Fen Bilgisi Programında Pozitivist Bilim Anlayışından Postpozitivist/Yapılandırıcı Sürece Geçiş
}

\author{
Faruk ÖZTÜRK ${ }^{\dagger}$
}

ÖZET: Bu çalışmanın amacı, Türkiye'de İlköğretim fen bilgisi dersinin, tarihsel süreçte uğradığ 1 dönüşümleri tespit ederek, amaç ve içerik boyutunda programa egemen olan paradigmaların etkisini ortaya koymaktır. Bu tarihsel süreçte iki aşama olarak ele alınmıştır. $\mathrm{Bu}$ iki aşamadan ilki, pozitivizmin egemen olduğu, Osmanlı Devletinin son dönemi ile Cumhuriyet dönemidir. İkinci aşama ise ve 2004 ve sonraki dönemdir. Bu süreçte, ilköğretim fen bilgisi dersi ve öğretimine egemen olan pozitivist bilim anlayışı ile 2004 tarihli ilköğretim programına egemen olan yapılandırıcı yaklaşımın değerlendirilmesi yapılmıştır. Çalışma doküman incelemesi yöntemiyle, içerik analizine dayalı olarak yürütülmüştür. Cumhuriyet döneminde egemen olan pozitivist bilim anlayışı ilköğretim programında, fen bilgisi dersinin amaç ve içeriğinde net olarak görülürken 2004 İlköğretim programında kısmen de olsa yapılandırıcı yaklaşımın postpozitivist epistemolojik etkisi söz konusudur. Fakat daha çok öğretim pratikleri ve stratejileri bağlamında ele alınmış, pedagojik düzlemden öteye geçememiştir.

Anahtar Sözcükler: İlköğretim programı, fen bilgisi, bilim, pozitivizm, yapılandırıcı yaklaşım

\footnotetext{
$\dagger \quad$ Doç. Dr., Abant İzzet Baysal Üniversitesi, Eğitim Fakültesi, Eğitim Bilimleri Bölümü, Bolu. e-posta: farukozturk2006@gmail.com.
} 


\section{GİRIS}

Türk eğitim tarihinde modernleşme ya da batılılaşma olarak adlandırılan sürece etki eden felsefelerden biri de pozitivizm olmuştur. Bununla birlikte son dönemde, pozitivist düşünceye ve pozitivist bilim anlayışına karş1 postpozitivist/postmodern yaklaşımların da bu sürece dâhil olduğu söylenebilir. $\mathrm{Bu}$ durum bilimsel ve epistemolojik açıdan hem pozitivist/modernist paradigma hem de son dönemlerde postmodersnist/postpozitivist paradigmalar olarak eğitim programlarında etkisini göstermiştir. Türk eğitim tarihinde, Fen Bilgisi dersi de, bu değişimin belirgin olarak yaşandığı bir ders olmuştur. $\mathrm{Bu}$ nedenle, bu çalışmada, gerek tarihsel süreçte-Osmanlının son dönemleri ve Cumhuriyet döneminde- gerekse 2004 yllından itibaren Türkiye'de uygulanmakta olan İlköğretim Programında yer alan Fen ve Teknoloji Dersi Öğretim Programı'nın amaç ve içeriğine etki eden epistemolojik yaklaşımların ne olduğunun saptanması ve egemen paradigmada yaşanan dönüşümün değerlendirilmesi amaçlanmıştır. $\mathrm{Bu}$ yaklaşımdan dolayı çalışmanın giriş̧ bölümünde, pozitivizm kavramı, Türkiye'ye girişi ve Fen Bilgisi kavramıyla ilişkisi, yüklenen anlamlar ve değişimler ele alınacaktır. Bulgular kısmında ise fen bilgisi dersine egemen olan temel epistemolojik yaklaşımın tezahürleri ortaya konulacaktır. Çalışmada kullanılan pozitivizm kavramı, modern bilimsel düşüncenin deney ve gözleme dayalı olarak temele aldığ 1 bilgi üretme biçimi anlamında kullanılmıştır. Programlarda bu yaklaşıma uyan ifade ve örnekler ile amaca yönelik öğretim yöntemleri ve öğrenme yaklaşımları pozitivizm kavramı kapsamında değerlendirilmiştir. Diğer taraftan 2004 sonrası yaklaşım için ise postpozitivist/postmodernist nitelemesi kullanılmıştır. Bunun nedeni, Milli Eğitim Bakanlığı [MEB]'nın resmi açıklamasında ve 2004 tarihli İlköğretim Programı'nda da belirtildiği gibi, "temel felsefe" ve "öğrenme yaklaşımı" olarak, postmodernist epistemolojinin eğitime transfer edilmiş hali olarak kabul edilen (Cromer, 1997; Fleury, 1998) "radikal yapılandırıcı yaklaşımın esas alınması" (MEB, 2006, s.8) indan dolayıdır. Dolayısıyla 2004 İlköğretim Programı nitelendirilirken, 'postmodern' kavramı kullanılmıştır. Postmodern epistemolojik yaklaşımların hemen hepsini ise postpozitivist bir yapıda değerlendirmek mümkündür.

\section{Pozitivizm, Türkiye'ye Girişi ve Fen Bilgisi}

Pozitivizm felsefesi, genel olarak teoloji ve metafizik açıklamalar içermeyen, sadece fiziksel dünyanın gerçeklerine dayanan bilim anlayışıdır. Pozitivist felsefeye göre bilimsel yargılar deney ve gözlemle ilişki içindedir. Bunun sonucunda da doğrulukları ve yanlışlıkları gösterilebilir. Olgularla desteklenen ya da olgularla ilgili verilere dayanan bilginin tek sağlam bilgi 
türü olduğunu savunan belirli bir düşünce biçimini ifade etmektedir. (Ural, 2006) Bu düşünce biçimi, bilimi tek geçerli bilme yöntemi ya da bilgi türü olarak ele alır. (Cevizci, 1996). Pozitivist bilim anlayışını temelinde yer alan bu düşüncelere göre, bilim ve bilgiye konu olan olgu ve varlıklar, mekanik, nedensel ve olgusal ilkelere tabidir. Ayrıca bu tür bilgi gelişimsel, ilerlemeli, birikimli, tutarlı ve test edilebilir özellikler taşıyan bir bilgidir. Bilgi sadece bilimsel yöntemlerle elde edilebilir. Bu bilimsel yöntemler de deney ve gözleme dayalı bir uslamlama sürecidir. (Ural, 2006) Pozitivist bilim anlayışı tarihsel olarak, Avrupa'da Aydınlanmanın ve Yeniçağ bilimlerindeki önemli gelişmelerin bir sonucudur. Bu felsefenin temelleri, Aydınlanma dönemi filozoflarından İngiliz ampirist Francis Bacon'a kadar gitmektedir. Bacon, gözlem ve deneyin temele alınıp bilimin bu esaslara göre yeniden kurulması gerektiğini savunmuştur.(Ural, 2006) Bu bakımdan pozitivizm, ampirist/deneyci felsefenin bir türüdür. Osmanlı devlet adamları ve düşünürlerinin, Batıda gelişen bu paradigma değişiminin farkına varmaları 19. yüzyılın öncesine kadar uzanmaktadır. Fakat ciddi olarak Batıya yöneliş ve batının bilimsel bilgi anlayışıyla etkileşim, Tanzimat döneminde, A. Comte'un Sadrazam M. R. Paşa'ya yazdığı 1853 tarihli "pozitivizme davet" mektubuyla üst noktalara taşınmıştır. Bu etkileşimin sonucunda Osmanlıya hem resmi hem de özel yollarla pozitivist düşünce 19. yüzyıldan itibaren girmiş ve özellikle okul programlarını ve programlardaki fen ve matematik temelli uygulamalı dersleri derinden etkilemiştir. $\mathrm{Bu}$ tarihsel süreç nedeniyle Türk eğitim tarihinde 'bilim' kavramı ile 'Fen bilgisi' kavramı arasında sıkı bir ilişki var olagelmiştir. Özellikle ilk kullanım şekliyle 'fen' kavramından kastedilen şey kısmen "bilim"” kısmen de Batı'nın teknolojisi, teknik bilgisidir. Osmanlı devletinin son dönemlerinde, eğitim alanında kullanılan bilim ve fen öğretimi kavramlarından kastedilen şey "pozitif bilim" dir. Bu konuda ilk söylem sahibi olan Kâtip Çelebi (Osmanlı Rönesans'ının başlatıcısı olarak kabul edilen) ilk olarak Batıda gelişen olgusal bilim anlayışının takip edilmesi ve alınmasını, Medrese'nin ürettiği bilgi ve bilme biçimlerinin (skolastik tarzın) terk edilmesini önerirken ilk kez olgusal tutumdan ve pozitivist anlamda bilimden bahseder (Adivar, 1982). Ayrıca ilk dönem askeri okullarda "ulum ve fünûn" (bilim ve fen) gibi derslerden kastedilen şey pozitif bilimleri kapsayan, pozitivist bilme ve bilgi üretme biçimleriyle oluşturulmuş derslerdir. Bugünkü anlamda fizik, kimya, biyoloji, fizyoloji, vb. doğa bilimleridir. Örneğin Ali Suavi 19. y.y.'da (Tanzimat döneminde) okulların programından bahsederken de, "zamanımızda her öğrencinin bilmesi gereken bilim, fen bilimleridir" (Ülken, 1992, s. 87) vurgusunu yapar. Aynı yaklaşıma göre eğitim olgusu da 'uygulamalı bir fen alanı' (Koçer,1987, s. 151) olarak ele alınır. Bu anlamda Osmanlıda bilimsel düşünce olarak "pozitivist" yönelimler resmi olarak ilk kez askeri okulların ders programıla kendini göstermiştir. İlk kurulan Askeri Kara Okulu'nda baş hocalık yapan İshak Efendi'nin yazdığ 
Mecmua-i Ulum-i Riyaziye adlı kitabı batıda gelişen pozitivist bakış açısını yurda taşımış ve Osmanlıca ürettiği fen ve matematik terimleriyle de ilk etkiyi yapmıştır (Tekeli, 1988). Diğer taraftan Tıp eğitimi için 1865 yılında Claude Bernard'ın, pozitivizmin öncü biyoloji kitabı olan, Introduction l'Etude de la Médecine Expérimentale çevrilmiş ve etkili olmuştur (Mardin, 1992). Özellikle askeri okullar için hazırlanan programlar bu etkinin giriş kapısı olmuştur. Osmanlı devlet adamı ve aydınları, gelişme ve ilerleme için, öncü rolün 'fen bilimleri' alanında olabileceğini vurgulamaya bașlamışlardır (Kafadar, 2000). Tanzimat döneminin bu yönelimi, Bat1 biliminin algılanışında meydana gelen değişimi en iyi şekilde ortaya koyar. Bu algı değişimini ülkeye yayacak olan da eğitim kurumlarıdır. Bilim ve teknolojinin elde edilmesinin yolu, bu algı değişimine uygun şekilde eğitimi düzenlemekten geçtiğine inanılmaktadır (Berkes, 1978). Diğer taraftan bazı sivil oluşumların çalışmasıyla ilk Batılı bilimsel düşünüş biçimleri yerleşmeye başlamış̧ır. Bu oluşumlardan Beşiktaş Cemiyet-i İlmiyesi (1815), Cemiyet-i İlmiye-i Osmaniye (1861) gibi dernekler yaptıkları çalışmalarında Osmanlı toplumunda batılı anlamda bilim ve fen bilgisi alanının gelişimini amaçlamışlardır. Kurucuları batıda özellikle pozitif bilimler alanında eğitim almış ve pozitivist düşünceyle tanışmış bilim adamlarıdır. Derneklerin amacı, Anglo-sakson bilim anlayışını memlekete sokmaktır (Berkes, 1978). Derneğin yayın organı Мecmuay-ı Fünun fen bilimlerine ilişkin yayınlarıyla ilk olma özelliğini taşır. Makalelerde ve Kimyager Derviş Paşa vb. aydınlar tarafindan verilen konferanslarda amaç, hem "yeni fenler hakkında bilgi vermek, endüstrinin gelişmesini ve zihinlerin aydınlanmasını teşvik etmek" (Berkes, 1978, 232) hem de Batı bilim ve tekniğinin alınmasına öncülük etmektir.

Osmanlının son dönemlerindeki egemen düşünceye göre Pozitivizm Batıda bilimle eş değer olduğu için Batı'ya açılmanın yolu pozitivizme açılmaktan geçer. Bu haliyle Pozitivizm, Tanzimat'tan (1839) Cumhuriyet'e kadar modernleşme sürecinde epistemolojik bir akım olmaktan çok bir yöntem olarak işgörmüş, meşrulaştırma sürecinde temel kavramların temelini soyut, dinsel ya da anlatısal (narrative) kaynaklara değil bilimsel bilgiye dayandırmıştır. Osmanlı aydınlarının Batı'da gelişen bu düşünsel akımlarla tanıştıkları dönemde, bu akımlara karşı felsefi/düşünsel alternatif çıkarma yetisinden yoksun oldukları için bu düşünceleri taklit yoluyla uygulamadan başka çareleri de yoktu. Çünkü bütün batılı olmayan toplumların modernleşmesi, Batı'nın aydınlanma süreci yaşanmadan gerçekleşmiştir (Özlem, 2002). 1870 yılından itibaren Osmanlı aydınları bilim ve siyaset öğretisi bağlamında da Fransız pozitivizminin sözcülüğü yapmışlardır. $\mathrm{Bu}$ dönem Osmanlı aydınının savunduğu bu pozitivizm, temelde 'fiziksel olgulara önem verme'(Mardin, 1993) anlamında olduğu da unutulmamalıdır. Etkilenme biçimi dönemsel olarak değişimler gösterse de başta siyaset olmak üzere, eğitim ve bilim anlayışını etkileyen bu pozitivist 
düşünce, A. Comte'un klasik pozitivizm anlayışıdır. Cumhuriyet döneminde 1950' li y1llara kadar her alanda özellikle eğitim programlarında klasik pozitivizm anlayış1 etkin olurken, 1950'lerden sonra ise genelde Anglosakson pozitivizminin etkisinden de bahsedilebilir (Özlem, 2002).

\section{YÖNTEM}

$\mathrm{Bu}$ çalışma “Türkiye'de Batılı anlamda bilimsel anlayışın eğitim alanına girişi, Türkiye ile Batı arasındaki tarihsel ve düşünsel ilişski çerçevesinde oluşan bir süreçte yerleşmiştir" argümanına dayanmaktadır. Diğer bir ifadeyle, hem Batıdaki bilimsel ilerleme ve gelişmenin etkisi, hem de batılılaşma sürecinde bu gelişmelerin benimsenmek istenmesi, bilimsel anlayışın Türkiye'ye girişinde ve gelişiminde temel etken olmuştur. $\mathrm{Bu}$ temel argümandan hareketle çalışmanın amacı Türkiye'de Fen Bilgisi öğretiminin içerik ve amaç açısından geçirdiği değişimlerin saptanmasıdır. $\mathrm{Bu}$ amaçla söz konusu alanın içeriğini oluşturan bilimsel bilgi ve bilimsel yöntem anlayışı, Fen Bilgisi programlarında kullanılan ifadeler ve kavramlar ortaya konularak yapılacaktır $\mathrm{Bu}$ amaçla şu sorulara cevap aranacaktır: (i) Illkögretim Fen Bilgisi programlarında yer alan konular ve kavramlar farklı amaçların etkisiyle değişime uğramış mıdır? (ii)Söz konusu tarihsel dönemlerde meydana gelen epistemolojik algı değişimleri programın içeriği ve amaçları üzerinde ne ölçüde etkin olmuştur?

Çalışma nitel bir yaklaşımla desenlenmiştir. Çalışma, tarihsel bazı resmi belgelere dayalı olarak program değerlendirmesi olduğu için nitel araştırma yöntemlerinden doküman incelemesi yöntemi kullanılarak gerçekleştirilmiş̧ir. Çalışmada Tanzimat döneminden başlayarak, konu ile ilgili eğitim programlarına ait dokümanların analizi yapılmıştır. Doküman incelemesi araştırılması hedeflenen olgu veya olgular hakkında bilgi içeren yazılı materyallerin analizini kapsar.(Yıldırım ve Şimşek, 2005) Çalışmanın konusunu içeren temel dokümanlar, Mekatib-i Íptidaiye ve Taliye Ders Programı, (1913), Illk Mekteplerin Müfredat Programı (1914), Ilk Mekteplerin Müfredat Programı, (1924, 1926 ) Illk Okul Programı (1936, 1948, 1968), İlköğretim Okulu Programı (1992) ve İlkögretim Programı (2004)'ndan oluşmaktadır. Bu dokümanların incelenmesi ve analizinde olas1 yanlılığın azaltılması için resmi programların orijinal metinleri (1913, 1914 ve 1926 programları birincil kaynaklar olan Osmanlıca metinler/ Milli Kütüphane EHT seksiyonundan temin edilerek) kullanılmıştır. $\mathrm{Bu}$ programlar Osmanlı dönemine ait Maarif Nezareti [MN]ya da Cumhuriyet dönemi Maarif Vekâleti [MV]veya MEB yayınlarından oluşan resmi belgelerdir. Araştırmaya konu olan dokümanları oluşturan resmi okul programları çalışmanın ana veri kaynağını oluşturmaktadır. Çalışmanın 
problemi kapsamında bu programların sadece Fen Bilgisi dersi, çalışma konusu olarak tespit edilmiştir. Dokümanlar, Türkiye'de ilköğretim basamağında gerçekleştirilen eğitim programları düzenlemesi ya da değişimlerini kapsayan belli tarihsel kesitleri temsil edecek şekilde seçilmiştir. Bu tarihsel dokümanlardan elde edilen veriler betimsel analiz yaklaşımına dayalı olarak incelenmiş̧ir. Betimsel analiz sürecinde, programlarda yer alan ders konularında ve amaçlarda/kazanımlarda kullanılan epistemolojik dil ve önermeler analitik bir yaklaşımla ele alınmıştır. Doküman seçiminde dikkat edilen ölçüt ise ilgili tarihlerde program değişimlerinin yaşanmasıdır. Bu şekilde programlarındaki değişimi y1llara göre ortaya koyarak, temel bilim felsefesinde ve epistemolojik tutumda görülen değişimleri karşılaştırılarak değerlendirilmiştir. Bu nedenle 2004 tarihli program, geleneksel yaklaşımdan temel bir kopuşu yansıttığı için, yukarıda seçilen tarihlere ait fen bilgisi programlarının (Osmanlı devletinin son çeyrek yüzyılına ve Cumhuriyet dönemine egemen olan pozitivist yaklaşım ile 2004 tarihli postmodernist yaklaşım) karşılaştırılması çalışmanın amaçladığı ana iki temel kesiti/aşamayı oluşturmaktadır. Bunun için çalışma kapsamında değerlendirilecek olan eğitim programlarındaki Fen Bilgisi dersinin amaçlar ve içerik bölümleri, programların ön incelemesi sonucunda oluşturulan bazı temel kategoriler altında kavramsallaştırılarak incelenmiştir. Bu kategorileştirmede söz konusu kategorileri oluşturan ilgili sözcükler ve içerik analiz birimi olarak kullanılmıştır.

Programlarda, fen bilgisi dersinde ele alına konu ve epistemolojik yaklaşımlar belirli bir tarzda kendini gösterdiği bazı dönemler birleştirilerek değerlendirme yapılmıştır. $\mathrm{Bu}$ şekilde oluşturulan dönemlendirme sonucunda, programda ilk olarak fen bilgisi dersinin/konularının yer aldığı 1913 ve 1914 tarihli program birinci grup olarak ele alınmış, ikinci grup olarak, Cumhuriyet dönemi ilk yıllarını içeren 1924, 1926 ve 1936 ilköğretim programları ele alınmıştır. Üçüncü grup olarak 1948, 1968 ve 1992 program değişimleri, dördüncü grup olarak da köklü değişimin öngörüldüğü 2004 ilköğretim programı(4.ve 5. sinıf) incelenmiştir. Programlar amaç ve içerik boyutunda incelenmiş ve epistemolojik vurguların yapıldığı kavram ve sözcükler belirli ve anlamlı bir kategori oluşturacak şekilde gruplandırılmıştır. $\mathrm{Bu}$ grupları oluşturan tematik ifadelerden tümevarımsal bir yaklaşımla belirli kategoriler oluşturulmuştur. $\mathrm{Bu}$ kategoriler, tüm program gruplarında ortak olmasına dikkat edilmiştir. Fakat dönemsel olarak ortaya çıkan ya da farklılık arz eden konu ve yaklaşımlar diğer gruplarda yer alan kategorilerden bağımsız olarak da yer alabilmiştir. Bu kategoriler oluşturulurken, programların amaçlar, (amaçlar içinde bazen yer alan dersin ilkeleri kısmı) ve içerik bölümleri dikkatlice okunarak, ilk olarak araştırmanın öngördüğü temaya ait sözcük, kavram ve cümleler tespit edilerek bir araya getirilmiştir. Buradan hareketle temel 
kategoriler ortaya çıkarılmıştır. Analiz birimi kavram ve sözcükler bir araya getirilirken, ilk olarak amaç ve içerik boyutları ayrı ayrı ele alınmış daha sonra kategoriler oluştuktan sonra karışık olarak sunulmuştur. $\mathrm{Bu}$ kategoriler, (i) yöntem olarak bilimsellik, (ii) Bilgide nesnellik ve olgusallı (iii) Nedensellik şeklinde oluşmuştur. Kategorilerin altında yer alan orijinal ifadelerin karşısına vurgu sıklığını belirten rakamlar da eklenerek bulgular sayısallaştırılmıştır.

\section{BULGULAR VE YORUMLAR}

Osmanlılar döneminde ilk olarak düzenli ve kapsamlı bir eğitim programı 1869 tarihli Maarifi Umumiye Nizamnamesi[MUN] ile başlar. İlk kapsamlı ilköğretim programı da 1913 tarihli Mekatib-i İptidaiye-i Umumiye programıdır. İlk kez ilköğretim kademesinde fen bilgisi alanına ait derse bu programda rastlamaktayız. Birinci grupta incelediğimiz dönem Osmanlı devletinin son yıllarını kapsamaktadır. Bu programda Malumat-ı Tabiiye ve Tatbikatı (1913) ve Eşya Dersleri(1914) dersleri yer almaktadır. Bu grup programın analizinde oluşan kategorilerde şu ifade ve vurgulardan oluşur (MUN, 1329[1913], ss. 34-41; MUN, 1330[1914], ss. 49-68):

Tablo 1: Temel kategoriler

\begin{tabular}{ll}
\hline 1. Yöntem olarak bilimsellik & 2. Bilgide nesnellik ve olgusallık \\
\hline (...) hakkında tetkikat(...)(6) & (...)uzvî mevcutların yekdiğerine yaptıkları \\
(...) üzerinde müşahede ve tecrübeler (...)(5) & mütekabil tesirler (...) \\
(...) üzerine tetkikat (...) ve konuşmalar(...)(2) & Nasıl hareket ediyoruz? \\
(...) tecrübe ettirilir (...)(2) & Nasıl hissediyoruz? \\
(...) müşahedeler (...) ve konuşmalar(2) & Nasıl teneffüs ediyoruz? \\
Insanın vücudundaki azalar ve vazifeleri (...) & Hararetin etkisi(...) hakkında konuşmalar \\
(...)Tabii olaylar hakkında tekkik (...) & Havanın bitkilere etkisi (...) \\
Çevrede bulunan böceklerin tetkiki (...) & Isı ve ziyanın bitkilere ve hayvanlara etkisi \\
\hline
\end{tabular}

$\mathrm{Bu}$ konuların sunuluş biçiminde ve uygulama boyutunda genellikle öğrencilere inceleme gözlem, örneklerden yararlanarak(sınıfa bitki ve hayvan vb. numuneleri getirerek, yada öğrencileri doğal ortamlara götürerek) konuları anlatma veya basit düzeyde onların gözlem ve deney yapabilmelerine dönük talimatlara da rastlanmaktadır. Programın içerik kısmında, "tetkik", "müşahede" gibi bilimsel inceleme ve gözlemi işaret eden kavramlar yer alsa da daha çok öğretmen tarafindan verilen bilgi ve "mükamelat" yani konuşmalarla dersin yürütülmesi öngörülmektedir. Dönemin eğitim kurumlarında öğrenim görmüş olan H. Ali Yücel söz konusu dönemde pozitif bilimlere ait derslerini eleştirirken, kara tahta fiziğ i ve tebeşir kimyasından başka bir ders görmediklerini vurgular.(Şengör, 2006) 


\section{Cumhuriyet dönemi ilköğretim programlarında Fen (Bilgisi) öğretimi}

Cumhuriyet dönemi eğitim anlayışının temel özelliği, pozitivist bilim temeline dayanan çağdaş eğitimin tüm ülkeye yayılmasıdır. Bunun için, Atatürk'ün 1923 tarihli meclis konuşmasında "memleket çocuklarının kazanmaya mecbur oldukları bilim ve fendir" (Ataünal ve Özalp, 1977, s. 35) ifadesiyle asıl amaç ortaya konulmuştur. Bu devrimsel yaklaşım, toplum ve devletin temeli olan kültür ve eğitim alanlarını köklü bir biçimde dönüştürmüş, pozitivist bilim anlayışıyla düzenlenen bir eğitim düzenine geçilmiştir (Gök, 1999). "İlerlemenin yolu olarak da bilimsel tutuma bağlanmak ve eskinin[skolastik dönemin] bütün düşünsel tutum ve kalıntılarından vazgeçmek zorunluluğu"(Berkes, 1978, s. 514) benimsenmiştir. $\mathrm{Bu}$ doğrultuda ikinci grupta incelediğimiz programlar sırasıyla; Tabiat tetkiki, ziraat hifzissihha (1924), Tabiat Dersleri (1926) ve Tabiat Bilgisi (1936) programlarıdır. Aşağıdaki kategorilerden oluşmaktadır (MV, 1340[1924], ss. 38-44: MV, 1926, ss. 82-87; KB (Kültür Bakanlığ1), 1936, ss. 111-124):

Tablo 2: Temel kategoriler

\begin{tabular}{|c|c|}
\hline 1. Yöntem olarak bilimsellik & 2. Bilgide nesnellik ve olgusallik \\
\hline $\begin{array}{l}\text { (...) müşahede ve tecrübeler (...)(8) } \\
\text { (...) hakkında tetkikat (...)(7) } \\
\text { Ameli malumat vermek(uygulamalı bilgi) (...)(2) } \\
\text { (...) tabiatı tetkik esasına göre tetkik (..) } \\
\text { Basit surette teşrih(kadavra incelemesi) (...) } \\
\text { (...) tecrübe ve tetkik usulüne istinad ettirmek.(3) } \\
\text { (...) doğrudan doğruya denemeler yaptırmak (..) } \\
\text { (..) düşünerek hükümlere varma (...) } \\
\text { Müşahede ve deneme için ekskürsiyonlar (...) }\end{array}$ & $\begin{array}{l}\text { Uzvî mevcutların yekdiğerine yaptıklar } \\
\text { mütekabil tesirler (...) } \\
\text { Nasıl hareket ediyoruz? } \\
\text { Nasıl hissediyoruz? } \\
\text { Hararetin etkisi (...) hakkında konuşma } \\
\text { Havanın bitkilere etkisi (...) } \\
\text { Su canlılarının yaşamı(...) } \\
\text { Beş duyu(...) görevleri (...) } \\
\text { Bir cismin suya batmasinın tecrübe ile } \\
\text { tetkiki }\end{array}$ \\
\hline \multicolumn{2}{|l|}{ 3. Nedensellik } \\
\hline \multicolumn{2}{|c|}{ 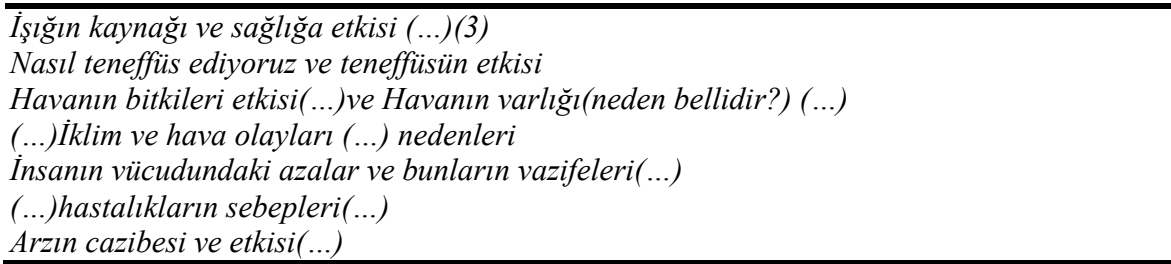 } \\
\hline
\end{tabular}

Erken Cumhuriyet dönemi fen bilgisi derslerinin genel özelliği olgucu, deneyci yaklaşımın daha basit ve temel düzeyde ele alınışıdır. Ayrıca ögretime ait bazı ilkelerde pozitif bilim anlayışının temel yöntem olarak ele alındığı görülmektedir. Yapılan "gözlem ve deney sonuçlarının kaydedilmesi" 
ve derste "sözel ve teorik sunumdan mümkün olduğu kadar kaçınılması" önerilmektedir. (MV, 1341[1925]) Cumhuriyetle birlikte pozitivist bilim anlayış1 doğrultusunda, Atatürk, ülke için geçerli olacak olan eğitimden bahsederken, "eski devrin hurafelerinden kurtulmuş, pozitif bilime dayanan bir eğitim" (Başgöz, 1995, p. 277) tanımını kullanır. Bu pozitivist yaklaşım, bilimsel rasyonellik, "en hakiki mürşit" olarak tanımlanır (Yavuz, 2009). Eğitim programlarının esas hedefi, "mevcut cehli (bilgisizlik) izale (gidermek) etmek, iptidai malumatı (temel bilgileri) ameli (uygulamal1/deneysel) bir tarzda vermek" (Yücel, 1994, s. 227) şeklinde belirtilmiştir. Derslerin, gözlem ve deneysel nitelikte olması, "denemeden inanma usulünden kurtarması" yeni programların asıl hedefi olarak gösterilmiştir.(Yücel, 1994) $\mathrm{Bu}$ doğrultuda oluşturulan ve içeriği yeniden düzenlenen ilkokul programlarından, üçüncü grupta ele alınan programlar, Tabiat Bilgisi (1948), Fen ve Tabiat Bilgileri (1968) ve Fen Bilgisi (1992) programlarıdır. Bunlar aşağıda şu şekilde kümelendirilmiştir(MV, 1948, ss.158-176; MEB, 1971, ss. 82-106; MEB, 1995, ss. 293-325):

Tablo 3: Temel kategoriler

\begin{tabular}{|c|c|}
\hline 1. Yöntem olarak bilimsellik & 2. Bilgide nesnellik ve olgusallık \\
\hline \multicolumn{2}{|c|}{ (...) gözlem ve deney yolunu öğrenme (...) Tabiata ait olaylar(...)(4) } \\
\hline$(15)$ & (...) maddeleri görünen ya da \\
\hline (...) bilimsel sonuçlar çıkarma (...)(6) & hissedilen özellikleri (...)(2) \\
\hline (...) gözlem deney, problem çözme & Maddenin elektriksel özellikleri (...) \\
\hline & \\
\hline (...) sonuçlara varmak için ne gibi & Bitkilerin kısımlarl ve görevleri (...) \\
\hline inceleme ve deneyler yapılması (...)(4) & gelişmesi(2) \\
\hline Akılcı ve bilimci davranışın & avrusunun gelişimini \\
\hline önemi $(\ldots)(4)$ & inceleme \\
\hline Bilimin insan hayatındaki yeri ve önemi & (...) varlıklarını, görerek, işiterek, \\
\hline 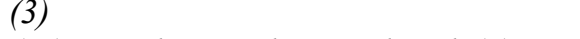 & dokunarak, koklayarak, tadarak \\
\hline (...) geçirdiğ & anları. \\
\hline (...) bilimsel metotlarla düşünme (...)(3) & (...) bütün maddeler atom denilen \\
\hline çözme (...)(2) inceleme (...) (2) Genel & $\begin{array}{l}\text { küçük yapı taşlarından meydana } \\
\text { gelmistir }\end{array}$ \\
\hline (...) gözlemleri yaptırmak(2) & Bilim ve teknolojinin toplumun \\
\hline Eski insanların (...) yanlış inanışları & ilerlemesinde etki ve önemi (...) \\
\hline$(\ldots)(2)$ & İşile enerji arasındaki ilişki (...) \\
\hline Gelenek ve adetlerin tesiriyle edinilmiş & Yağmur, kar, sis, bulut (...) oluşumu \\
\hline $\begin{array}{l}\text { yanlıs ve esassiz fikirler } \\
\text { hatıl inanclar nelerdir? }\end{array}$ & kayalart inceleyerek \\
\hline "Hayatta en hakiki mürşit il & \\
\hline prensibi & \\
\hline Bilim gö & \\
\hline
\end{tabular}


değiştirmiştir(...)

Bilimin bulacă̆ ç̧ok şeyler vardır.(...)

Insanlar araştıra araştıra (...)

bulmuşlar.

3. Nedensellik

(...) tabii olayların sebeplerini de kavramaya ve açıklamaya (...)

Havanın basincı(...) değişir, rüzgâr, kar (...) bu değişmelerden olur.

Güneş ışık, ısı ve hayat kaynağıdır.

Bütün canlılar yaşamak ve üremek için birbirine muhtaçtırlar.

(...) ısinin etkisi ile(...)

Dünyamızın (...) toprağın meydana gelişi

Güneş olmadan yaşayamayız ve güneşin canlıları yaşatması

Havanın varlığını etkileriyle anlarız

Bütün canlılar hücreden yapılmıştır (...) vücudumuzun sistemlerden oluştuğunu

(...)

Bitkinin ışı̆̆a, suya, havaya ve madensel maddelere ihtiyacl

Yediğimiz yemeklerin enerji ve hareket să̆laması

Cisimleri görmemize yarayan ışı (...)

Bir cismin renkli görünüşünün sebebi(...)

Bu böceklerin... Çeşitli hastalıklara sebep olduklarını

Besinlerden enerji sağlandı ̆̆ (...)

\section{Fen ve Teknoloji programı: Pozitivist yaklaşımlar Yapılandırıcı Beklentiler}

Yukarıda ele alınan dönem, materyalist ontolojik temelden hareketle yerleşen pozitivist yaklaşıma dayalı bir program anlayışının görüntüsünü sunmaktadır. Son günlerde, önceki programlara egemen olan pozitivist bilim anlayışına karşı farklı bir paradigma söz konusudur. Bu farklı yaklaşım, "postmodern/postpozitivist epistemoloji”ye dayanan yapılandırıcı öğrenme yaklaşımı olarak ifade edilmektedir. Yapılandırıcı yaklaşım, özellikle epistemolojik bağlamda ortaya çıkan "radikal" yapılandırıcılık, öğrenme ve öğretim süreçlerine vurgu yapmaktan öte asıl olarak "bilmenin" ne olduğu ve bilgiye ulaşmanın nasıl olduğuna (Phillips, 1995, s. 11; Fosnot, 2005, s. IX) vurgu yapar. Bilgi ise aktarılan ve keşfedilen gerçekler değil, gelişimsel, nesnel olmayan ve uygulanabilir /tutarlı açıklamalar olarak ele alınır. Postmodern döneme geçişte bilim ve bilgi anlayışında yaşanan dönüşümlerin etkisi tüm dünyada olduğu gibi, küreselleşmenin de bir uzantısı olarak, Türkiye'de de eğitim programlarında etkisini göstermektedir. MEB'in resmi yetkilileri uygulanan yeni programda yer alan yapılandırıcı yaklaşımla pozitivist bilim anlayışını sorgulamaya koyulduklarını, (Birinci, 2006) belirtirler. MEB'in resmi yetkilileri, eleştirel yaklaşımlarında, pozitivist 
bilim ve bilgi kuramı eleştirisinden öteye geçerek, pozitivizmin meşrulaştırcı etkisinin toplumsal ve politik yapıda iş görmesine yönelirler ve bu temel nedenden hareket ederler. Bu nedenle yapılandırıcı yaklaşıma epistemolojik olmaktan çok politik bir vurguyla sarıldıkları görülmektedir. Bu doğrultuda 1980'lerden itibaren, dünyada en etkili yaklaşım haline gelen yapılandırıcılık, birçok ülkede olduğu gibi, Türkiye'de de eğitimin resmi felsefesi haline gelmiştir (Ünder, 2010). 2004 Fen ve Teknoloji Dersi programının "amaçları" ve "programın vizyonu" bölümünde, bir "öğrenme yaklaşımı" olarak "diğer öğrenme kuramlarını reddetmemekle beraber (...) faydalı ve işlevsel bir çerçeve sağladığı için" (MEB, 2006, s. 12) yapılandırıcılığın, benimsendiğini görmekteyiz.

2004 programında yer alan bazı ifadeler incelendiğinde, programın yapılandırıcı epistemoloji anlayışını kısmen yansıttı̆̆ söylenebilir. Örneğin, fen alanının özellikleri tanımlarken (MEB, 2005, ss 63-151; MEB, 2006, ss. 4-8; 12; 23;60-61); fen alanına dünyadaki her kültürden bilim adaminın katkısı (...),fen, farkl kültürlerden birçok kadın ve erkeğin katkıda bulunduğu (...),fen, bireysel ve sosyal bir faaliyettir, akademik tartışmalarda karşıllkkl diyalog ve ikna sureci yaşanır (...),fen, sosyal, kültürel, ekonomik ve dinsel etmenlerden ve kişisel velveya toplumsal ön yargllardan etkilenir, Dünyamızın hep siyah ve beyazlardan oluşmadiğl gerçeği sezgisel olarak kavratılır, gibi söylemler, "bilimi durağan, değişmez gerçekler bütünü olarak görmeyen ve etkin, organize bir süreci ilgilendirdiğini” (Glasersfeld, 2005, s. 3; Julyan and Duckworth, 2005, s. 71) ima eden yapılandırıcı yaklaşımla bağdaşabilir ifadelerdir. Diğer taraftan, Programda, bilimsel bilgilerin doğruluğu konusunda dogmatik değil, yanılabilirci bir bilim anlayışının benimsendiği de görülmektedir. Örneğin, fen ve teknoloji dersinin bazı kazanımlarında, "uzay hakkında bilinen gerçeklerin sınırlı ve yeni araştırmalarla değişebilir (...) fen alanındaki bilgiler, değişmez gerçekler değil, halen bilinen en iyi açıklama" (MEB, 2005, s. 282) şeklinde yer alan ifadeler; "mevcut bilimsel önermeler biçiminde biriken bilgiye her zaman meydan okumalar olabilir" (Lyotard 1999, s. 37) görüşüne uyan, öznelciyanılabilirci postmodern bilim anlayışına bir gönderme olduğunu söyleyebiliriz. Öğrenme ile ilgili olarak da, "bilgi ve beceriler, öğretmenden öğrenciye olduğu gibi aktarılamaz, kişisel bilgi, görüş, inanç öğrenmeyi etkiler", ve "bilgi ve anlayışlar her birey tarafindan kişisel ve sosyal olarak yapılandırılır"'(MEB, 2006, s. 13) gibi ifadeler de yapılandırırıcı öğrenme yaklaşımını yansıtmaktadır. Fakat bütün bu vurgular yanında programın "temel felsefe" olarak benimsenen yapılandırıcı yaklaşıma uymayan bazı çelişik yaklaşımların olduğu da bir gerçektir. "Temel felsefe" kavramı belirsiz olmakla birlikte "öğrenme yaklaşımı" ifadesinden farklı olduğu için yapılandırıcılığın epistemolojik temelini işeret eden ve öğrenen bireyin 
zihinsel aktivitesini ön plana alan "radikal yapılandırıcılığa" karşılık gelir. Aslında fen programında ön plana çıkarılan, constructivist epistemolojinin bilim anlayışı değil, bu yaklaşımın öğretim sürecine sunduğu alternatiften yararlanmaktır. Program yapılandırıcı yaklaşımı hem temel felsefe olarak ele alır hem de fen bilgisi alanını, "yapılandırıcı öğrenme yaklaşımına en az uyan bir ders" (s. 7) olarak ilan eder. Böylece yaklaşımın sadece öğretim etkinliklerinde yararlanılacağını ima etmektedir. Öğretim stratejileri ile ilgili olarak, "programda, yapılandırıcı öğrenme yaklaşımı öncelikli olup" (MEB, 2006, s. 11) ifadesi ile sadece yapılandırıcı öğrenme yaklaşımının esas alınmadığını, bunun dışında, pozitivizimle paralel nesnelci, deterministik, doğrusalc1, davranışçı öğrenme ve öğretim yaklaşımlarının da esas olduğu çıkarsanabilir. Programda her ne kadar yapılandırıcı felsefe temele aldığı iddia edilse de, çoğu temel noktalarda pozitivist yaklaşımdan uzaklaşılamadığı söylenebilir. Bunlar aşağıda temel kategoriler altında şu şekilde yer almaktadır (MEB, 2005, ss. 63-258):

Tablo 4: Temel kategoriler

\begin{tabular}{|c|c|}
\hline 1. Yöntem olarak bilimsellik & Bilgide nesnellik ve olgusallık \\
\hline 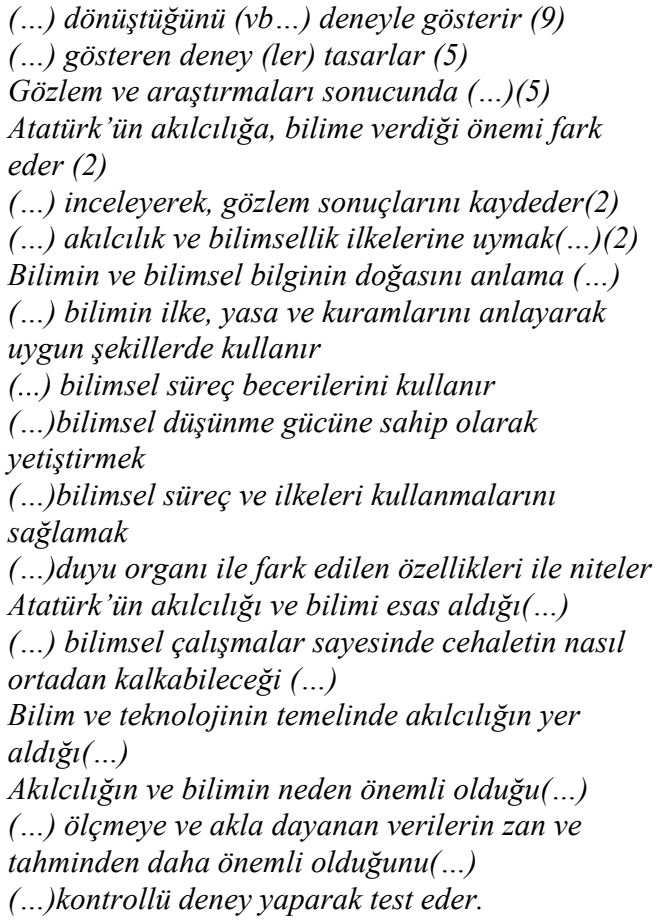 & $\begin{array}{l}\text { (...) varlığını nasıl fark edebileceğini } \\
\text { açılklar } \\
\text { (...) olduğunu göstermek için deney } \\
\text { tasarlar } \\
\text { (...) gösteren bir deney yapar } \\
\text { Gözlemlerine dayanarak her sesin bir } \\
\text { kaynağı olduğu (...) } \\
\text { (...) yüzdürerek (..) mümkün olduğu } \\
\text { çıarımını yaparlar } \\
\text { (...) doğru olup olmadı̆̆ını basit } \\
\text { deneylerle sınarlar } \\
\text { Bilimsel ölçme sonuçlarının yer ve } \\
\text { zaman değişse de birbirine yakın } \\
\text { çıkacağını (...) } \\
\text { Gözlemlerine dayanarak (...)olduğu } \\
\text { sonucunu çıkarır. } \\
\text { Sesin katı, sıvı ve gaz ortamlarda } \\
\text { yayılabileceğini deneylerle gösterir. } \\
\text { Mikroskobik canlıların (...) etkisini } \\
\text { deney yaparak gözlemler. }\end{array}$ \\
\hline
\end{tabular}




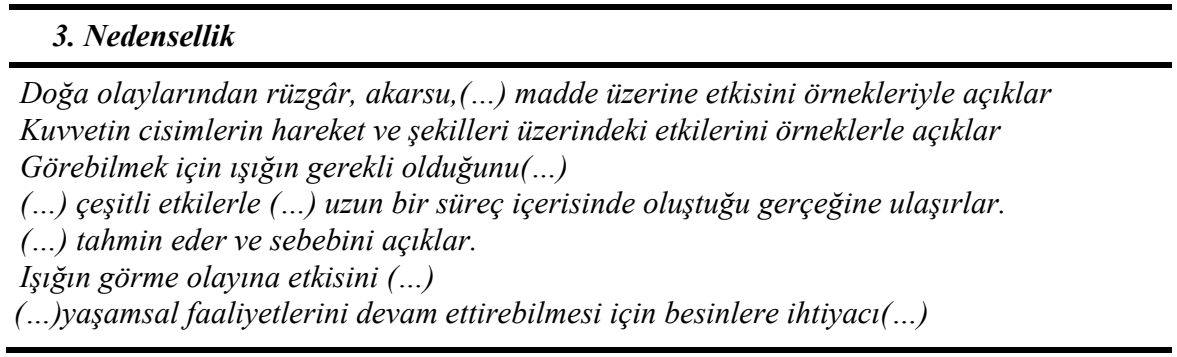

Özellikle Tablo 4'te yer alan amaç ve içerik maddeleri, Ünder (2010)'in yorumuna göre, modernist aydınlanmacı ve nesnelci bilim anlayışına verilen ayrıcalıklı konumu gösterir. Ayrıca programda, Atatürk'ün bilimi ve akılcılığı diğer düşünsel gelenekler karşısında ayrıcalıklı bir konuma koyduğu görüşüne yapılan göndermelerden (MEB, 2005, s.106; s. 122) dolayı da programın bilim anlayışı, yapılandırıcı anlayıştan çok pozitivist aydınlanmacı anlayışa daha yakındır. Diğer taraftan programda, "Fennin değişime daha az uğrayan boyutu yöntemleridir. Bilimsel yöntemlerin yerleşmesi hedefi gözetilmiştir" (MEB, 2006, s. 7) denilerek, özellikle bilginin meşruluğu tartışmalarında en önemli boyutu oluşturan modernist aydınlanmacı bilgi üretim yönteminin esas alındığı vurgulanmaktadır. Genel olarak 2004 programında pozitivist ve postpozitivist değerler iç içe geçmiş ve adeta bir denge gözetilmiştir. Daha çok öğrenme stratejileri bağlamında yapılandırıcı yaklaşımın esas alındığı söylenebilir. Fakat Bilgide nesnellik ve olgusallık kategorisinde ise kaçınılmaz olarak pozitivist perspektif egemendir. Özellikle bilgi düzeyinde kazanımların net olarak yazılmış olması bile pozitivist anlayışın bir tezahürüdür. Bu kazanımlar, yapılandırıcı yaklaşımın "iki kişinin aynı yapıyı ürettiğini söylemek imkânsızdır"(Glasersfeld, 2005, s. 6) düşüncesinden uzak bir anlayıştır. Kazanımlarda kullanılan "gerçek" sözcügüu, nesnelerin zihinden ve kuramlardan bağımsızlı̆̆ını ifade eder. Ayrıca bu ve benzeri nesnelci ve gerçekçi bilme anlayışı da genel olarak öğretmen tarafindan gerçekleştirilmesi istenen kazanımları oluşturmaktadır. Program, radikal yapılandırıcı felsefeye uygun olmayan ve öznel algıları çok da hesaba katmayan bir tutumu hala devam ettiren bir yaklaşıma sahiptir. "Fiziksel ve biyolojik dünya" varsayımı ve "bu dünya, kişinin tecrübe dünyasından bağımsız olarak vardır" (MEB, 2005, s. 121) ifadesiyle tamamen nesnelci ve pozitivist bir yaklaşımı benimser. Ayrıca, "Fen, sadece dünya hakkındaki gerçeklerin bir toplamı değil, deneysel ölçütleri (...) temel alan bir araştırma ve düşünme yoludur (...) bilimsel yöntemleri içerir" (MEB, 2005, s. 8) açıklaması gerçek dünyanın resmini elde etmeye çalışan pozitivist epistemolojik geleneğin paralelinde bir açıklamadır. 


\section{SONUC}

Tüm Bilim tarihinde olduğu gibi, Türkiye'de de bilimsel düşüncenin pozitivizmle ilşkisi oldukça eskidir. Fakat bu ilişki resmi okul programları kanalıyla öğretimi etkilemesi Osmanlı devletinin son çeyrek yüzyılına rastlar. Egemen bilme biçimi olan pozitivist yaklaşımın özellikle fen bilgisi alanına etkisi doğal bir gelişmedir. Bütün dünya da olduğu gibi Türkiye'de de bilimsel bilgi anlayışı ile pozitivist yaklaşımın paralelliği söz konusudur. Fen bilgisi programının özellikle ilköğretim düzeyinde ele aldığ 1 kazanım ve uygulamalar bu realist ve pozitivist çerçevede 2004 tarihine kadar egemen olan paradigmayı yansıtmıştır. Fakat 2004 tarihli program değişikliği bu paradigmaya karşı alternatif ve postpozitivist yapılandırıcı yaklaşımı kazanımların temeline yerleştirmeye çalıştığ 1 görülmektedir. Bu ise fen bilgisi gibi bir alanda köklü bir bakış açısı değişimi demektir. Bu değişim programda kazanımlar boyutunda gerçek anlamıyla yansıtılamamıştır. Yansıması da alan gereği ve toplumsal yapı ve bilim felsefesi açısından köklü bir zihinsel dönüşümü gerektireceği için mümkün olması zor bir durumdur. Çalışmada görüldüğü gibi yapılandırıcı yaklaşımın fen bilgisi alana dönük öğrenme kazanımları ve hedeflerinde yer alan yaklaşımları pozitivist ve nesnelci bilim anlayışından farklı hiçbir şey ortaya koyamamaktadır. $\mathrm{Bu}$ ise yönelimin sadece ideolojik ve kültürel bir direnç saikıyla yaklaşıldığı düşüncesini güçlendirmektedir. Oysaki konu tamamen epistemolojik ve pedagojik amaçlarla tartışılması gerekirken Türkiye gibi benzer geleneksel ülkelerde bu yaklaşımlar politik amaçlarla gündeme geldiği görülmektedir. Epistemolojik alt yapısının ne anlama geldiği tam kestirilmeden ve bilginin inanç ve bireysel/öznel algıya indirgenmesi özellikle fen bilgisi öğretiminde nasıl bir sonuç vereceği tartışılması gereken bir konudur. Ayrıca bilim eğitimi alanında, bilimin temeli olan nesnel gerçekliğin öznelleştirilerek, ilerleme ve çağdaşlaşmanın daha kolay elde edileceği savı, en azında Aydınlanma sürecini yaşamayan topluluklar için yanıltıcı bir sürece neden olabilir.

\section{KAYNAKLAR}

Adıvar, A.(1982). Osmanlı Türklerinde ilim. Ankara.

Ataünal, A. ve Özalp, R. (1977) Türk milli eğitiminde düzenleme teşkilatı. İstanbul: ME. Basımevi.

Başgöz, İ. (1995). Türkiye’nin eğitim çıkmazı ve Atatürk. Ankara: Kültür Bakanlığı Yayınları.

Berkes, N. ( 1978). Türkiye’de çă̆daşlaşma. İstanbul. 
Birinci, N. (2006). Protokol konuşmaları. Türk eğitim sisteminde yeni paradigma arayışlart. 03. 02. 2010 tarihinde http://www.egitimbirsen.org.tr/dokuman/ sempozyum_kitabi.pdf adresinden alınmıştır.

Cromer, A. (1997). Connected knowledge: Science, philosophy and education. New York: Oxford Uni.Press.

Fleury, S. C. (1998). Social studies, trivial constructivism and the politics of social knowledge. Larochelle, M. \& Bednarz, N. \& Garrison, J.(Eds.). Construnctivism and Education. Cambridge : Cambridge U. Press:

Fosnot, C. T. (2005). Constructivism: Theory, perspectives and practice (Ed. C. T. Fosnot). N.Y. : T.C. Press.

Gök, F. (1999). 75 yılda insan yetiştirme eğitim ve devlet. 75 yllda eğitim (Ed. F. Gök). İst.: T. V. Yay., 1-23.

Julyan, C.\& Duckworth, E. (2005). A Conctructivist perspective on teaching and learning science. constructivism: Theory, perspectives and practice (Ed. C. T. Fosnot). NY: Teachers C. Press, 55-72.

Koçer, H.A. (1987). Türkiye'de modern eğitimin doğuşu. Ankara: Uzman Yayınları.

Lyotard, J-F. (1999). The Postmodern condition- A report on knowledgeMinnesota: The University of Minnesota Press.

MUN (1329/1913). Mekatib-i iptidaiye ve taliye ders programı. İstanbul: Matbaa-i Amire.

MUN (1330/1914). Mekatib-i iptidaiye ve taliye ders programı. İstanbul: Matbaa-i Amire.

MV (1340/1924). Illk mekteplerin müfredat programi. İstanbul: Matbaa-i Amire.

MV (1925). Illk mekteplerin müfredat programı. İstanbul: Matbaa-i Amire.

MV (1926). Illk mekteplerin müfredat programı. İstanbul: Milli Matbaa.

MV (1930). Illk mektep müfredat programı. İstanbul: Devlet Matbaas1.

KB (1936). Illkokul programi. İstanbul: Devlet basımevi.

MEB (1948). Illkokul programı. İstanbul: ME. Basımevi.

MEB (1971). Illkokul programı. İstanbul: ME. Basımevi.

MEB (1995). Illkögretim okulu programı. Ankara: MEB Yayınları.

MEB (2005). Fen ve teknoloji dersi (4 ve 5. siniflar) ögretim programi. 03. 01.2011 tarihinde http://tkb.meb.gov.tr/program.aspx?islem=1\&kno=24 adresinden alınmıştır.

MEB (2006). Fen ve teknoloji dersi (6, 7 ve 8. sinfflar) ögretim programı. 03. 01. 2011 tarihinde http://ttkb.meb.gov.tr/program.aspx?islem $=1 \& \mathrm{kno}=25$ adresinden alınmıştır.

Özlem, D. (2002). Türkiye'de pozitivizm ve siyaset. Modern Türkiye'de siyasi düşünce- modernleşme ve batıcıllk.(Ed. T.Bora) İstanbul: İletişim, 452-464.

Phillips, D. C. (1995). The good, the bad and the ugly: The many faces of constructivism. Educational Researcher, 24, 5-12.

Ülken, H. Z. (1992). Türkiye'de çağdaş düşünce tarihi. İstanbul: Ülken Yayınları.

Ünder, H. (2010). Manifestations of epistemological theses of constructivism in the science and technology programs of Turkish elementary education. Education and Science, 35, 199-214. 
von Glasersfeld, E. (2005). Thirty years radical constructivism. Constructivist Foundation, 1, 9-12.

Yavuz, H. (2009). Türkiye'nin zihin tarihi. İstanbul: Timaş Yayınları.

Cevizci, A. (1996). Felsefe sözlüğ̈̈. Ankara: Ekin Yayınları.

Ural, Ş. (2006). Pozitivist felsefe. İstanbul: Say Yayınları.

Şengör, M. C. (2006). Cumhuriyet bilim ve eğitim politikası ve hasan ali yücel. Atatürk Döneminden Günümüze Cumhuriyetin Eğitim Felsefesi ve Uygulamaları Sempozyumu Bildirileri. Ankara: Gazi Üni. Rektörlüğü Yay., 133-175.

Yücel, H.A. (1994) Türkiye’de orta öğretim. Ankara: Kültür Bakanlı̆̆ı Yayınları. 